\title{
A remarkable teratological case in Chigallia simplex Linnavuori \& DeLong, 1977 (Hemiptera: Auchenorryncha: Cicadellidae)
}

\author{
Un notable caso teratológico en Chigallia simplex \\ Linnavuori \& DeLong, 1977 (Hemiptera: Auchenorrhyncha: Cicadellidae)
}

Eduardo I. Faúndez ${ }^{1} \&$ Juan F. Campodonico ${ }^{2}$

\begin{abstract}
A case of wing asymmetry based on the atrophy of right tegmen and hindwing is described for Chigallia simplex. This case is the first teratosis known for a Chilean cicadellid and one of the few cases described for Auchenorrhyncha.
\end{abstract}

\section{Key words:}

Membracoidea, Megophthalminae, Agalliini, wing asymmetry, atrophy, Chile.

\section{Resumen}

Se describe un caso de asimetría alar basado en la atrofia del tegmen y el ala posterior izquierda para Chigallia simplex, siendo el primer caso teratológico conocido para un cicadélido chileno y uno de los pocos casos descritos para Auchenorrhyncha.

\section{Palabras clave:}

Membracoidea, Megophthalminae, Agalliini, asimetría alar, atrofia, Chile.

\section{INTRODUCTION}

Teratoses are singular events that occur on individuals, influencing their ontogenetic development. However, these events can last on the time, and display on the phylogeny of a determined linage (Ortuño \& Ramos, 2008). At world level, the major works on teratology on Hemipterans were undertaken by Balazuc (1952) and Štusák and Stehlík (1977, 1978, $1979,1980,1982)$. The majority of examples documented in these works, however, are from families mostly in the suborder Heteroptera (Faúndez \& Rider, 2017).

Chigallia Linnavuori \& Delong, 1977 is an endemic genus of Agalliini leafhoppers and is composed of three species distributed between Bío Bío and Los Lagos regions (Linnavuori \& DeLong, 1977). Chigallia simplex Linnavuori \& Delong, 1977 is the shorter species and is characterized by tegmina with brown veins and without brown irroration nor extra crossveins at clavus. C. simplex has been recorded for Puyehue (Osorno Province), Corral (Valdivia Province) and Quellón (Chiloé Province) (Linnavuori \& DeLong, 1977). The purpose of this contribution is to describe a remarkable teralogical case on this species.

\section{MATERIALS AND METHODS}

In terminology and classification, we follow Balazuc (1952) and Štusák and Stehlík (1982). For identification, we follow Linnavuori and DeLong (1977). Photos were taken with a digital camera adapted to a stereoscopic microscope. All measurements are in millimeters. The specimen

\footnotetext{
1 Laboratorio de Entomología, Instituto de la Patagonia, Universidad de Magallanes, Av. Bulnes 01855, Casilla 113-D, Punta Arenas, Chile.

$\bowtie$ ed.faundez@gmail.com

2 J.M. Perceval 10259, Vitacura, Santiago, Chile. juan.campodonico@ug.uchile.cl
} 
studied is deposited in the collection of the second author Juan F. Campodonico.

\section{RESULTS}

Wing asymmetry in Chigallia simplex (Fig. 1)

The right tegmen and hindwing of the specimen are atrophied and shortened (Fig. 1 a and $b$ ). The tegmen is ovate in lateral view, with rounded and entire apex, whereas the hindwing is shortened and totally covered by the tegmen (Fig. $1 \mathrm{~b}$ and $\mathrm{c}$ ). Both wings on the left side are normal. The claval suture of malformed tegmen is complete; only two veins are present at corium (apparently $\mathrm{R}$ vein is vanished), the anterior vein (apparently $\mathrm{M}$ vein) is curved posteriorly near middle, fusing with the posterior vein (apparently $\mathrm{Cu}$ vein) enclosing a cell, and then reaching the margin at the end of claval suture; the two anal veins are complete at clavus. No distinct venation is visible on posterior malformed wing. There are no signs of external pressure, cystelitry, trematelytry or any similar malformation (only creasing of the malformed hind wing due to the manipulation). Additionally, the rest of the specimen (including the thorax) is normal, not having any other areas of the body atrophied or malformed.

Measurements: length of left (normal) tegmen 3.15; right (atrophied) tegmen 1.82. Length of left (normal) hind wing 2.75; right (atrophied) hind wing 0.99 .

Material examined: Chile, Los Lagos Region, Llanquihue Province, Río Blanco, Lago Chapo, 6. II. 1983, R. Honour leg. 1 female.

\section{DISCUSSION AND CONCLUSION}

This is the first known teratological case for a Chilean cicadellid, however, the absence of known cases may be a result of the lack of collecting and prospection for the group in the country.

There are few teratological cases described for Auchenorryncha (Balazuc, 1951) from these most of them belong to venation anomalies and genital malformations, not concentrated in cephalic or thoracic ones as in other Hemiptera. The causes of these include sometimes external pressures as well as disease or parasitism in early stages of development of the specimen (Balazuc, 1951; Štusák \& Stehlík, 1982). In the case of wing malformations, Balazuc (1951) mentioned only one case known from a Cicadidae species in
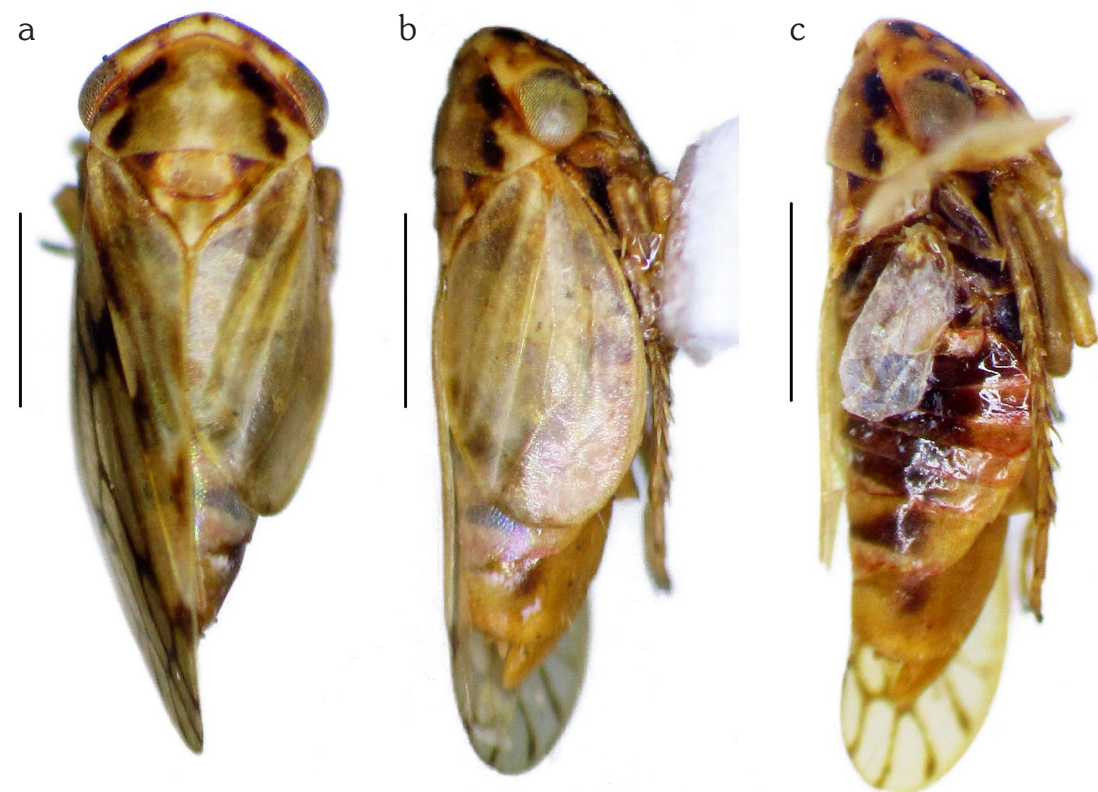

Fig. 1. Teratological specimen of Chigallia simplex. a. Dorsal view, b. Lateral view. c. Lateral view, hind wing exposed. Scale bars: $1 \mathrm{~mm}$. 
Japan. On the other hand, cases on Cicadellidae are mostly associated with atrophies caused by parasites on diverse sections of the body. The case in which the atrophied wing is entire are scarce within Hemiptera. Furthermore, these including both fore and hind wing of a single side are less common. Štusák and Stehlik (1982) wrote that in Tingidae (Heteroptera) some of these cases may be the result of a disease in a very early stage, thus having the malformation even on the pterotheca in the nymphal stages. This case seems to follow that pattern, because there is no sings of external pressure or mutilation, and the malformed wings are entire and not irregularly deformed. Additionally, the few vein malformations in the malformed wings seem to be just a secondary consequence of the atrophy. Although, that seem to be the more reasonable explanation for this case we cannot disregard the possibility of an endogenous cause for the malformation. However, further studies and experiments are needed on this family to better understand the malformations of wings.

\section{ACKNOWLEDGEMENTS}

We are grateful to Richard Honour for providing the specimen used in this study.

\section{LITERATURE CITED}

Balazuc, J. (1951). La tératologie des Hémiptères et groupes voisins. Annales de la Société Entomologique de France, 120, 17-66.

Faúndez, E. I., \& Rider, D. A. (2017). Two teratological cases in Hillieria acuminata Distant, 1910 (Heteroptera: Pentatomidae:
Pentatominae: Aeptini). Boletín de la Sociedad Entomológica Aragonesa, 60, 353-354.

Linnavuori, R., \& DeLong, D. M. (1977). The leafhoppers (Homoptera: Cicadellidae) known from Chile. Brenesia, 12/13, 163267.

Ortuño, V. M., \& Ramos Abuin, J. A. (2008). Reflexiones sobre la teratología y descripciones de cuatro teratosis apendiculares en Coleoptera. Boletín Sociedad Entomológica Aragonesa, 43, 435-439.

Štusák, J. M., \& Stehlík, J. L. (1977). First contribution to the teratology of Tingidae (Heteroptera) reflexion and variability of paranota. Acta Musei Moraviae, Scientiae biologicae, 62, 119-122.

Štusák, J. M., \& Stehlík, J. L. (1978). Second contribution to the teratology of Tingidae (Heteroptera) Antennal anomalies. Acta Musei Moraviae, Scientiae biologicae, 63, 89-105.

Štusák, J. M., \& Stehlík, J. L. (1979). Third contribution to the teratology of Tingidae (Heteroptera) Anomalies of legs. Acta Musei Moraviae, Scientiae biologicae, 64, 75-84.

Štusák, J. M., \& Stehlík, J. L. (1980). Fourth contribution to the teratology of Tingidae (Heteroptera). Anomalies of head and thorax. Acta Musei Moraviae, Scientiae biologicae, 65, 161-172.

Štusák, J. M., \& Stehlík, J. L. (1982). Fifth contribution to the teratology of Tingidae (Heteroptera). Anomalies of fore wings (Hemelytra). Acta Musei Moraviae, Scientiae biologicae, 67, 163-180. 